\title{
Current treatment of soft tissue sarcoma
}

\author{
Shawn Steen, MD, and Gerald Stephenson, MD
}

S arcomas are rare tumors, representing only $0.8 \%$ of new cancers in the United States. Seventy-six percent arise in soft tissue, with the remainder arising in bone (1). The most common soft tissue type is malignant fibrous histiosarcoma, although this has fallen out of favor recently as a distinct histologic entity (2, 3). Multiple types of soft tissue sarcomas are defined based on the tissue of origin (Table 1). Of those occurring in the soft tissue, most present in the extremities. The relative overall frequency of locations are thigh, buttock, and groin, $46 \%$; torso, $18 \%$; upper extremity, $13 \%$; retroperitoneal, 13\%; and head and neck, $9 \%$ (1). The most frequent presentation is as an asymptomatic mass. These tumors can present late, especially in the thigh or pelvic regions (3).

\section{STAGING}

The TNM stage is based on the major prognostic factors of tumor size, grade, depth in relationship to investing fascia, and metastatic disease (4) (Table 2). Grade is determined based on number of mitoses, presence of necrosis, cellular and nuclear morphology, and degree of cellularity. Five-year survival for stages I, II, III, and IV are approximately 90\%, 70\%, 50\%, and $10 \%$ to $20 \%$, respectively (1).

Magnetic resonance imaging with gadolinium is the preferred method for imaging extremity sarcomas. Since the lung is the most common site of distant metastasis, a computed tomography scan of the chest to identify pulmonary metastasis should be done in large, high-grade tumors (1).

The risk of developing metastatic disease is related to the size of the primary (5). Lesions 5.1 to $10 \mathrm{~cm}$ have a $34 \%$ risk of metastasis; 10.1 to $15 \mathrm{~cm}, 43 \%$; and 15.1 to $20 \mathrm{~cm}, 58 \%$ (6). Once macroscopic metastatic disease is evident, the median survival is 11 months, with a 5 -year survival of only $10 \%$ to $20 \%(1,4)$. Lymph node metastasis is considered stage IV disease and is rare
Table 1. Histologic classification of soft tissue sarcomas*

\begin{tabular}{|c|c|c|c|}
\hline Type & Benign & $\begin{array}{l}\text { Intermediate } \\
\text { (locally aggressive) }\end{array}$ & Malignant \\
\hline $\begin{array}{l}\text { Tumors of } \\
\text { adipose tissue }\end{array}$ & $\begin{array}{l}\text { Lipoma } \\
\text { Angiolipoma } \\
\text { Lipoblastoma } \\
\text { Hibernoma } \\
\text { Myolipoma } \\
\text { Angiomyolipoma }\end{array}$ & $\begin{array}{l}\text { Atypical lipoma/ } \\
\text { well-differentiated } \\
\text { liposarcoma }\end{array}$ & $\begin{array}{l}\text { Dedifferentiated liposarcoma } \\
\text { Myxoid liposarcoma } \\
\text { Pleomorphic liposarcoma } \\
\text { Round cell liposarcoma } \\
\text { Mixed-type liposarcoma }\end{array}$ \\
\hline $\begin{array}{l}\text { So-called } \\
\text { fibrohistiocytic } \\
\text { tumors }\end{array}$ & $\begin{array}{l}\text { Giant cell tumor of } \\
\text { the tendon sheath } \\
\text { Diffuse-type giant } \\
\text { cell tumor } \\
\text { Deep benign } \\
\text { fibrous histiocytoma }\end{array}$ & $\begin{array}{l}\text { Plexiform } \\
\text { fibrohistiocytic tumor } \\
\text { Giant cell tumor of } \\
\text { soft tissues }\end{array}$ & $\begin{array}{l}\text { Pleomorphic malignant fibrous } \\
\text { histiocytoma (MFH)/undifferentiated } \\
\text { pleomorphic sarcoma } \\
\text { Giant cell MFH/undifferentiated pleo- } \\
\text { morphic sarcoma with giant cells } \\
\text { Inflammatory MFH/undifferentiated } \\
\text { pleomorphic sarcoma with } \\
\text { prominent inflammation }\end{array}$ \\
\hline $\begin{array}{l}\text { Tumors of } \\
\text { skeletal muscle }\end{array}$ & Rhabdomyoma & & Rhabdomyosarcoma \\
\hline $\begin{array}{l}\text { Tumors of } \\
\text { smooth muscle }\end{array}$ & $\begin{array}{l}\text { Deep leiomyoma } \\
\text { Genital leiomyoma } \\
\text { Angioleiomyoma }\end{array}$ & & Leiomyosarcoma \\
\hline $\begin{array}{l}\text { Perivascular } \\
\text { tumors }\end{array}$ & Glomus tumor & & Malignant glomus tumor \\
\hline
\end{tabular}

except in certain subtypes such as synovial cell, epithelioid, clear cell, and rhabdomyosarcomas (1).

Excisional biopsy of suspected sarcomas is advocated only for superficial masses $<5 \mathrm{~cm}$ in size as long as $1-$ to $2-\mathrm{cm}$ margins can be obtained (7). The local recurrence rate in this group is expected to be around $8 \%$ if negative margins are obtained (1). Larger masses should be considered strongly for core needle or

From the Department of Surgery, Baylor University Medical Center, Dallas, Texas (Steen), and the Department of Surgery, John Peter Smith Hospital, Fort Worth, Texas (Stephenson).

Corresponding author: Shawn Steen, MD, Resident, Department of Surgery, Baylor University Medical Center, 3500 Gaston Avenue, Dallas, Texas 75246 (e-mail: ShawnSte@BaylorHealth.edu). 
incisional biopsy using proper techniques. Core needle should be attempted first, with incisional biopsy reserved for cases in which pathologic diagnosis cannot be made from the needle biopsy. Any incision should be made with the intention of excising the scar and tract with any further surgery. On the extremities, one must remember to make incisions along the long axis to allow reexcision and primary closure without the need for skin grafts. There should be no raising of flaps or disturbance of tissue planes superficial to the tumor, and meticulous hemostasis should be obtained to prevent tumor cell dissemination from a hematoma (3). Some recommend closed suction drainage to prevent postoperative seromas, with the drain site planned appropriately for reexcision as well (5).

\section{APPROACHES TO CLINICAL MANAGEMENT}

The management of newly diagnosed sarcoma is complicated. The therapeutic goals are improving survival, avoiding local recurrence, maximizing function, and minimizing morbidity (1). Surgical excision remains the dominant curative therapy (8). The exceptions are those patients who are medically inoperable or those who decline surgery if it entails unacceptable functional loss (1). Surgical excision of selected lung or liver metastasis has been performed with some improvement in survival.

Decision-making is more difficult in tumors considered high risk. High-risk soft tissue sarcomas are defined as high-grade, $>5$ $\mathrm{cm}$ in size, locally recurrent, deep to investing fascia, having previous inadequate surgery or positive margins, and certain subtypes such as leiomyosarcoma or malignant peripheral nerve sheath tumors (6). It is estimated that approximately half of those who have high-risk features will ultimately die from metastatic disease present as a microscopic foci at the time of diagnosis (4). The timing and order of wide local resection, preoperative or postoperative radiotherapy, and preoperative or postoperative chemotherapy require a multidisciplinary approach (6). Unfortunately, multimodal therapy differs considerably among major cancer centers (7). Being treated at a center with experience in sarcoma is important. Survival and functional outcomes are significantly better when patients are treated at a center with access to multimodal teams, including surgeons, orthopedic surgeons, medical oncologists, radiation oncologists, and experienced pathologists (1).

\section{SURGERY}

The line between unresectable and resectable sarcomas can be blurry. The goal of curative surgical excision is en bloc excision of the tumor and any biopsy tracts with a negative margin of normal tissue of 1 to $2 \mathrm{~cm}$ (7). There is wide agreement that a "shelling out" of the tumor with a blunt plane of dissection along the tumor leads to a high rate of local recurrence (7). Traditionally, soft tissue sarcomas of the extremities were often treated with amputation. As long as the entire tumor is removed, less radical limb-sparing procedures have not been demonstrated to adversely affect local recurrence or outcome (8). Amputation is now reserved for the small proportion of patients with massive tumors, extensive involvement of the neurovascular bundle, and nonfunctional limbs at presentation (1). Compartment excision from insertion to origin of the muscle is no longer generally
Table 2. TNM staging of soft tissue sarcomas*

\begin{tabular}{|c|c|c|}
\hline \multirow[t]{3}{*}{$\begin{array}{l}\text { Definition } \\
\text { of TNM }\end{array}$} & $\begin{array}{l}\text { Primary } \\
\text { tumor }(T)\end{array}$ & $\begin{array}{l}\text { TX: Primary tumor cannot be assessed } \\
\text { T0: No evidence of primary tumor } \\
\text { T1: Tumor } 5 \mathrm{~cm} \text { or less in greatest dimension } \\
\text { T1a: superficial tumor } \\
\text { T1b: deep tumor } \\
\text { T2: Tumor more than } 5 \mathrm{~cm} \text { in greatest dimension } \\
\text { T2a: superficial tumor } \\
\text { T2b: deep tumor } \\
\text { Note: Superficial tumor is located exclusively above the } \\
\text { superficial fascia without invasion of the fascia; deep } \\
\text { tumor is located either exclusively beneath the superficial } \\
\text { fascia, superficial to the fascia with invasion of or through } \\
\text { the fascia, or both superficial yet beneath the fascia. } \\
\text { Retroperitoneal, mediastinal, and pelvic sarcomas are } \\
\text { classified as deep tumors. }\end{array}$ \\
\hline & $\begin{array}{l}\text { Regional } \\
\text { lymph } \\
\text { nodes (N) }\end{array}$ & $\begin{array}{l}\text { NX: Regional lymph nodes cannot be assessed } \\
\text { N0: No regional lymph node metastasis } \\
N 1{ }^{*} \text { : Regional lymph node metastasis } \\
\text { *Note: Presence of positive nodes (N1) is considered } \\
\text { Stage IV. }\end{array}$ \\
\hline & $\begin{array}{l}\text { Distant } \\
\text { metastasis } \\
(\mathrm{M})\end{array}$ & $\begin{array}{l}\text { MX: Distant metastasis cannot be assessed } \\
\text { MO: No distant metastasis } \\
\text { Ml: Distant metastasis }\end{array}$ \\
\hline \multirow{4}{*}{$\begin{array}{l}\text { Stage } \\
\text { grouping }\end{array}$} & I & T1a, 1b, 2a, 2b; N0; M0; G1-2, G1 Low \\
\hline & $\|$ & T1a, 1b, 2a; N0; M0; G3-4, G2-3 High \\
\hline & III & T2b; N0; M0; G3-4, G2-3 High \\
\hline & IV & $\begin{array}{l}\text { Any T; N1; M0; Any G, Any G High or Low } \\
\text { Any T; N0; M1; Any G, Any G, High or Low }\end{array}$ \\
\hline \multirow{5}{*}{$\begin{array}{l}\text { Histologic } \\
\text { grade (G) }\end{array}$} & GX & Grade cannot be assessed \\
\hline & G1 & Well differentiated \\
\hline & G2 & Moderately differentiated \\
\hline & G3 & Poorly differentiated \\
\hline & G4 & $\begin{array}{l}\text { Poorly differentiated or undifferentiated } \\
\text { (four-tiered systems only) }\end{array}$ \\
\hline
\end{tabular}

*Used with the permission of the American Joint Committee on Cancer (AJCC), Chicago, Illinois. The original source for this material is the AJCC Cancer Staging Manual, 6th ed. (2002) published by Springer Science and Business Media LLC, www.springlink.com.

recommended, as it is associated with an increase in complications from radiation and recovery. Wide local excision with a normal margin of tissue around the tumor is the current surgical goal. The feasibility of limb-sparing resection is dependent on the morbidity associated with removing any surrounding structures. This can take into consideration that a margin of 1 to $2 \mathrm{~mm}$ of fascia, tendon, or bone is different than a similar margin of loose fatty or connective tissue (7). Resection and reconstruction of major arteries can be done with similar oncologic outcomes, and major bone resection and reconstruction can be done with implantable endoprostheses. Resection of major nerves such as the sciatic can be overcome to the point that patients can learn to walk independently with the use of ankle foot orthosis and tendon transfers (7). Microscopic residual tumor can sometimes be permitted along major vessels, nerves, 
or bone when additional resection would result in significant loss of limb function. These microscopically positive areas can be marked with metallic clips, and postoperative radiation can be delivered to the tumor bed (5). As technology and surgical audacity march forward, the distinction between resectable and unresectable tumors changes constantly, and a surgeon must be aware of the options and current data.

\section{CHEMOTHERAPY}

Chemotherapy has poor results in treating sarcoma. The role of adjuvant chemotherapy remains controversial because of the absence of convincing level 1 evidence that it improves overall survival (OS) $(6,9,10)$. A large metaanalysis of over 1500 patients with soft tissue sarcomas treated with adjuvant doxorubicin-based chemotherapy showed no significant improvement in OS (11). Adjuvant chemotherapy is still not regarded by many as standard treatment for resected primary soft tissue sarcomas, although it plays a role in metastatic or unresectable sarcomas (9). In regard to chemotherapy, the most important decision facing surgeons attempting curative resections of primary soft tissue sarcomas is the use of neoadjuvant therapy.

Neoadjuvant chemotherapy is indicated in the treatment of rhabdomyosarcoma because, unlike most sarcomas, high response rates are seen in this subtype (8). For other histologic subtypes of soft tissue sarcoma, the role of neoadjuvant chemotherapy remains controversial (8). Proponents of neoadjuvant chemotherapy feel that the response of the sarcoma to neoadjuvant therapy can sometimes be used to guide further treatment or for prognosis (4). A study from M. D. Anderson Cancer Center found that sarcoma response to preoperative chemotherapy provides strong prognostic information and can identify a subgroup of patients most likely to benefit from traditional adjuvant chemotherapy or those who should be considered for second-line or experimental treatments (10). Additionally, smaller tumors have a higher growth fraction and are potentially more chemosensitive. The larger the tumor becomes, the more likely a chemoresistant clone will spontaneously arise (4). Neoadjuvant chemotherapy may also allow treatment of occult metastatic disease that would have otherwise established new tumor growth while the patient recovers from major surgery. Neoadjuvant chemotherapy may also provide a test of biology, and if metastases become apparent in chemoresistant patients, they could be spared an otherwise morbid surgery.

Opponents of neoadjuvant chemotherapy argue that the toxicity of the drugs can weaken patients to the point that large surgical resections may become too morbid. Studies have shown that neoadjuvant chemoradiation can be associated with significant treatment and perioperative morbidity (6). Others are concerned that disease progression during neoadjuvant chemotherapy may render patients inoperable. In a large European study, the progression rate was $18 \%$ during neoadjuvant chemotherapy, and a recent prospective American trial found a 14\% progression rate $(5,9)$. The decision to attempt neoadjuvant chemotherapy must be weighed against the potential benefits and be individualized to particular patient circumstances, as there is no current consensus regarding its use.
Typical chemotherapeutic agents used in sarcomas are doxorubicin and ifosfamide. The MAID regimen is a common combination and consists of mesna, doxorubicin, ifosfamide, and dacarbazine. AIM, another common chemotherapy regimen, consists of doxorubicin, ifosfamide, and mesna (12).

Doxorubicin, trade name Adriamycin, is an anthracycline antineoplastic agent. It intercalates with DNA, affecting replication and protein synthesis. It also produces free radicals that destroy the cell membrane and mitochondria. The only defense cells have against these caustic free radicals is the enzyme glutathione peroxidase that converts the radical form back to inert oxygen. Unfortunately, cardiac muscle cells are essentially devoid of this enzyme and also have the highest concentration of mitochondria in the body. This results in the occasionally severe cardiotoxicity seen with the use of agents such as doxorubicin (13).

Ifosfamide was derived from the mustard gases used during World War I first by the German forces and eventually by the Allied forces as well. Mustard gas would incapacitate soldiers by causing deep blisters on exposed skin, eyes, and mucous membranes and eventual pulmonary failure. In 1943, a US supply of mustard gas exploded during a bombing in Italy, exposing thousands of citizens and troops. During the cleanup, medical workers noted that patients' white blood cell counts had decreased. The compound was adapted into medicine first as a treatment for lymphoma. Ifosfamide alkylates DNA by binding guanine molecules and forming cross-links between the double strands leading to cell death. The drug affects any organ undergoing frequent cellular division, including bone marrow, hair, and mucosa, leading to myelosuppression and hemorrhagic cystitis (14). It is active in many solid tumors including sarcoma. Mesna is used to prevent hemorrhagic cystitis. Dacarbazine is another DNA-alkylating chemotherapy agent sometimes used as an adjunct in sarcoma treatment.

The data supporting the use of neoadjuvant chemotherapy in soft tissue sarcoma largely consist of small retrospective series with very few randomized controlled trials. The results vary among studies. At best, doxorubicin and ifosfamide have objective response rates in sarcoma of $20 \%$ to $30 \%$ (4). The combination of the two shows a slightly higher response rate but at the expense of higher toxicity, especially myelosuppression $(4,15)$.

Surgery and radiation alone for soft tissue sarcomas historically has a reported 5-year disease-free survival (DFS) of 45\% and a 5-year OS of 60\% (16). As shown in Table 3, some studies have shown a trend towards increased DFS and OS with the use of neoadjuvant chemotherapy and radiation $(4,10,15$, 16). The Massachusetts General Hospital group has published two separate studies showing 5 -year DFS of $70 \%$ to $84 \%$ and 5 -year OS of $87 \%$ to $93 \%$ with the use of neoadjuvant chemoradiation $(4,15)$. Other studies have shown that the patients most likely to benefit from neoadjuvant chemotherapy are those with soft tissue sarcomas in the high-risk category such as those $>8-10 \mathrm{~cm}$, high grade, or recurrent $(5,12)$. Some studies, though, have not shown a significant improvement in survival with the use of neoadjuvant chemotherapy. A large European study by Gortzak et al did not demonstrate any 
Table 3. Summary of studies of neoadjuvant therapy in soft tissue sarcomas

\begin{tabular}{|c|c|c|c|c|}
\hline Study & $\begin{array}{l}\text { Patients } \\
\text { (n) }\end{array}$ & Study design & Outcome & Conclusion \\
\hline $\begin{array}{l}\text { Pezzi, } 1990(10) \text {, } \\
\text { from M. D. Ander- } \\
\text { son Cancer Center }\end{array}$ & 46 & $\begin{array}{l}\text { Neoadjuvant cyclophosphamide, } \\
\text { Adriamycin, dacarbazine in extremity } \\
\text { sarcoma }>5 \mathrm{~cm} \text { without metastasis } \\
\text { followed by surgery + radiation; } \\
\text { control = surgery + radiation alone }\end{array}$ & $\begin{array}{l}40 \% \text { clinical response rate. } \\
\text { Of responders, OS of } 60 \text { mo treatment } \\
\text { vs } 32 \text { mo control }(P=0.02) \text { and DFS } \\
\text { of } 60 \text { mo treatment vs } 15 \text { mo control } \\
(P=0.04) \text {. }\end{array}$ & $\begin{array}{l}\text { Tumor response to preoperative } \\
\text { chemotherapy provides strong prognostic } \\
\text { information and identifies a subgroup } \\
\text { of patients most likely to benefit from } \\
\text { chemotherapy. }\end{array}$ \\
\hline $\begin{array}{l}\text { Gortzak, } 2001 \text { (9); } \\
\text { EORTC trial }\end{array}$ & 134 & $\begin{array}{l}\text { Neoadjuvant AlM followed by surgery } \\
\text { in patients with high-risk sarcomas } \\
\text { defined as }>8 \mathrm{~cm} \text {, grade } 2 \text { or } 3 \text {, locally } \\
\text { recurrent, previous inadequate surgery; } \\
\text { control = surgery + radiation alone }\end{array}$ & $\begin{array}{l}\text { In neoadjuvant chemotherapy arm, } \\
8 \% \text { complete response, } 29 \% \text { overall } \\
\text { response, } 53 \% \text { stable, and } 18 \% \text { progres- } \\
\text { sive disease. } 5 \text {-yr OS of } 65 \% \text { treatment } \\
\text { vs } 64 \% \text { control, and } 5 \text {-yr DFS of } 56 \% \\
\text { treatment vs } 52 \% \text { control. }\end{array}$ & $\begin{array}{l}\text { Power of study too low for accurate } \\
\text { survival benefit but it did not demonstrate } \\
\text { any survival advantage for neoadjuvant } \\
\text { chemotherapy use. }\end{array}$ \\
\hline $\begin{array}{l}\text { Delaney, } 2003 \text { (5), } \\
\text { from Massachusetts } \\
\text { General Hospital }\end{array}$ & 48 & $\begin{array}{l}\text { Neoadjuvant MAID + radiation followed } \\
\text { by surgery and adjuvant MAID; control } \\
=\text { surgery + radiation alone }\end{array}$ & $\begin{array}{l}5 \text {-yr OS of } 87 \% \text { treatment vs } 58 \% \\
\text { control, and } 5 \text {-yr DFS of } 70 \% \text { treatment } \\
\text { vs } 42 \% \text { control. Wound healing complica- } \\
\text { tions } 29 \% \text { in neoadjuvant treatment arm. }\end{array}$ & $\begin{array}{l}\text { After aggressive neoadjuvant chemoradia- } \\
\text { tion and surgery, patients show a signifi- } \\
\text { cant reduction in distant metastasis with a } \\
\text { significant increase in DFS and OS. }\end{array}$ \\
\hline $\begin{array}{l}\text { Grobmyer, } 2004 \\
\text { (12), from Memorial } \\
\text { Sloan-Kettering } \\
\text { Cancer Institute }\end{array}$ & 74 & $\begin{array}{l}\text { Neoadjuvant chemotherapy AIM in } \\
\text { high-grade sarcoma }>5 \mathrm{~cm} \text {; } \\
\text { control = surgery + radiation alone }\end{array}$ & $\begin{array}{l}3-y r \text { DFS of } 83 \% \text { treatment vs } 62 \% \\
\text { control. No difference in tumors } 5-10 \\
\mathrm{~cm} \text { in size. }\end{array}$ & $\begin{array}{l}\text { Neoadjuvant chemo with AlM improves } \\
\text { DFS in patients with high-grade sarcoma } \\
>10 \mathrm{~cm} \text {. }\end{array}$ \\
\hline $\begin{array}{l}\text { Eilber, } 2004 \text { (11), } \\
\text { from Memorial } \\
\text { Sloan-Kettering } \\
\text { Cancer Institute }\end{array}$ & 245 & $\begin{array}{l}\text { Neoadjuvant doxorubicin in } 34 \% \text { of } \\
\text { patients vs neoadjuvant ifosfamide } \\
\text { in } 26 \% \text { of patients vs surgery alone } \\
\text { in } 40 \% \text { in patients with high-grade } \\
\text { primary extremity liposarcoma }>5 \mathrm{~cm}\end{array}$ & $\begin{array}{l}\text { No difference in 5-yr survival between } \\
\text { neoadjuvant doxorubicin and control. } \\
\text { There was a significantly improved } 5-y r \\
\text { DFS with use of neoadjuvant ifosfamide } \\
\text { of } 92 \% \text { vs } 65 \% \text { for control. }\end{array}$ & $\begin{array}{l}\text { In patients with }>5 \mathrm{~cm} \text {, high-grade, } \\
\text { primary extremity liposarcoma, neoadju- } \\
\text { vant ifosfamide-based chemotherapy is } \\
\text { associated with improved DFS. }\end{array}$ \\
\hline
\end{tabular}

OS indicates overall survival; DFS, disease-free survival; MAID, mesna, doxorubicin (Adriamycin), ifosfamide, and dacarbazine; EORTC, European Organisation for Research and Treatment of Cancer; AIM, doxorubicin (Adriamycin), ifosfamide, mesna; RTOG, Radiation Therapy Oncology Group.

survival advantage for the use of neoadjuvant chemotherapy (9). Currently, the studies available give no clear answer as to whether neoadjuvant chemotherapy definitively improves survival in soft tissue sarcoma.

Why, after over 3 decades of research, have we not answered this question? First, many studies have been too small to show significant survival benefit. Second, patients with low-risk features have been included in some studies, thus diluting any effect of chemotherapy. Lastly, many studies include patients that have been treated with either substandard doses of effective agents or combinations of agents known to have poor activity in sarcomas (4). Because of the lack of good data and consensus, there is no general recommendation regarding the timing and use of neoadjuvant therapy even in high-risk sarcoma except to say that the preoperative use of neoadjuvant chemotherapy may be justified in carefully selected high-risk patients with large, high-grade tumors (8).

\section{RADIATION}

Radiation can be an effective treatment to decrease local recurrence of soft tissue sarcomas (1). In a randomized trial by the National Cancer Institute, limb-sparing surgery alone had a recurrence rate of $22 \%$ compared with a recurrence rate of $<5 \%$ in patients receiving adjuvant radiotherapy (17). Adjuvant radiotherapy has not been shown to improve OS or decrease the incidence of distant metastases (17). The current National Comprehensive Cancer Network guidelines recommend radiation therapy for extremity sarcomas for high-grade lesions, low-grade lesions $>5 \mathrm{~cm}$, or positive margins $(8,17)$. Patients with reexcisions should also receive adjuvant radiotherapy $(1,9)$. Superficial low-grade sarcomas $<5 \mathrm{~cm}$ in size resected with wide margins do not need adjuvant radiotherapy (17).

There are potential advantages and disadvantages to both preoperative and postoperative radiation use. Preoperative radiation can reduce tumor burden before resection, allowing more 
conservative or function-sparing surgical therapy (17). The improved oxygenation of the tissue will theoretically increase the kill fraction of radiation from free radical-induced damage. This allows for a smaller field and a lower radiation dose of 50 Gy versus 66 to 70 Gy used in the adjuvant setting (17).

The preoperative use of radiotherapy is associated in some series with a significant increase in perioperative morbidity, particularly in wound complications $(1,6)$. Delaney et al at the Massachusetts General Hospital found the use of neoadjuvant radiation was associated with a $29 \%$ wound healing complication rate. Wound complications can be minimized by judicious use of muscle flaps and good wound coverage. A large randomized trial from Canada evaluating preoperative versus postoperative radiotherapy found that recurrence and progression-free survival were the same between the groups (18). In this study, radiation-associated wound complications were more common in the preoperative radiation group - $\mathrm{a} 33 \%$ wound complication rate versus $16 \%$ in the postoperative radiation arm (18). The preoperative radiation group had fewer toxic skin effects and late fibrosis than the postoperative group. These data support using preoperative radiation in justified cases to provide better long-term functional outcomes (17). For example, patients with upper-extremity tumors should be considered for preoperative radiation given the lower risk for radiation-associated wound complications and the desire to minimize long-term edema and fibrosis. In contradistinction, for upper thigh lesions where wound complications are most frequent, postoperative radiation might be a better choice (19). For large deep-seated tumors, preoperative radiation is more effective in preventing local tumor recurrence (1). Neoadjuvant radiation therapy is often combined with chemotherapy when chemotherapy is used in a preoperative or clinical trial setting.

Radiotherapy may be used after surgery for a variety of unforeseen reasons. Among these are the incidental diagnosis of sarcoma at surgery, upgrading of the tumor based on pathology or intraoperative findings, and the inability to obtain negative margins (17). Adjuvant radiation in this setting is given with a $>60$ Gy dose and 5 -cm margins of the radiation field (17). When deciding between preoperative versus postoperative radiation therapy, the type of surgical procedure to be performed, wound closure and tension, extent of the operative bed, likelihood of obtaining negative margins, and grade of the sarcoma should be considered (17).

\section{CONCLUSION}

While advances have been made, the treatment of soft tissue sarcoma still has much room for improvement. It is certainly an arena where cooperation between surgeons, medical oncologists, and radiation oncologists with significant clinical experience with these tumors is paramount. High-risk patients should be managed by a multidisciplinary treatment team. Consideration should be given to enrolling patients with high-risk tumors into clinical trials. Research must be continued in an attempt to improve treatment of this deadly disease.

\section{Acknowledgments}

We would like to thank Dr. Ronald Jones and Dr. John Preskitt for reviewing this article.
1. Nedea EA, DeLaney TF. Sarcoma and skin radiation oncology. Hematol Oncol Clin North Am 2006;20(2):401-429.

2. Eilber FC, Tap WD, Nelson SD, Eckardt JJ, Eilber FR. Advances in chemotherapy for patients with extremity soft tissue sarcoma. Orthop Clin North Am 2006;37(1):15-22.

3. Fiser SM. Plastics, skin, and soft tissues. In The ABSITE Review. Baltimore: Lippincott Williams \& Wilkins, 2007.

4. Scurr M, Judson I. Neoadjuvant and adjuvant therapy for extremity soft tissue sarcomas. Hematol Oncol Clin North Am 2005;19(3):489-500.

5. DeLaney TF, Spiro IJ, Suit HD, Gebhardt MC, Hornicek FJ, Mankin HJ, Rosenberg AL, Rosenthal DI, Miryousefi F, Ancukiewicz M, Harmon DC. Neoadjuvant chemotherapy and radiotherapy for large extremity softtissue sarcomas. Int J Radiat Oncol Biol Phys 2003;56(4):1117-1127.

6. Kraybill WG, Harris J, Spiro IJ, Ettinger DS, DeLaney TF, Blum RH, Lucas DR, Harmon DC, Letson GD, Eisenberg B. Phase II study of neoadjuvant chemotherapy and radiation therapy in the management of high-risk, high-grade, soft tissue sarcomas of the extremities and body wall: Radiation Therapy Oncology Group Trial 9514. J Clin Oncol 2006;24(4):619-625.

7. Cheng EY. Surgical management of sarcomas. Hematol Oncol Clin North Am 2005;19(3):451-470.

8. Singer S, Brennan M. Soft tissue sarcomas and bone tumors. In Townsend CM, Beauchamp DR, Evers BM, Mattox KL, eds. Sabiston Textbook of Surgery: The Biological Basis of Modern Surgical Practice, 17th ed. Philadelphia: Elsevier, 2004:803-829.

9. Gortzak E, Azzarelli A, Buesa J, Bramwell VH, van Coevorden F, van Geel AN, Ezzat A, Santoro A, Oosterhuis JW, van Glabbeke M, Kirkpatrick A, Verweij J; EORTC Soft Tissue Bone Sarcoma Group and the National Cancer Institute of Canada Clinical Trials Group/Canadian Sarcoma Group. A randomised phase II study on neo-adjuvant chemotherapy for 'high-risk' adult soft-tissue sarcoma. Eur J Cancer 2001;37(9):10961103.

10. Pezzi CM, Pollock RE, Evans HL, Lorigan JG, Pezzi TA, Benjamin RS, Romsdahl MM. Preoperative chemotherapy for soft-tissue sarcomas of the extremities. Ann Surg 1990;211(4):476-481.

11. Eilber FC, Eilber FR, Eckardt J, Rosen G, Riedel E, Maki RG, Brennan $\mathrm{MF}$, Singer $\mathrm{S}$. The impact of chemotherapy on the survival of patients with high-grade primary extremity liposarcoma. Ann Surg 2004;240(4):686695.

12. Grobmyer SR, Maki RG, Demetri GD, Mazumdar M, Riedel E, Brennan MF, Singer S. Neo-adjuvant chemotherapy for primary high-grade extremity soft tissue sarcoma. Ann Oncol 2004;15(11):1667-1672.

13. Ritch PS, Occhipinti SJ, Cunningham RE, Shackney SE. Schedule-dependent synergism of combinations of hydroxyurea with Adriamycin and 1-beta-D-arabinofuranosylcytosine with Adriamycin. Cancer Res 1981;41(10):3881-3884

14. Kerbusch T, de Kraker J, Keizer HJ, van Putten JW, Groen HJ, Jansen RL, Schellens JH, Beijnen JH. Clinical pharmacokinetics and pharmacodynamics of ifosfamide and its metabolites. Clin Pharmacokinet 2001;40(1):41-62.

15. Edmonson JH, Ryan LM, Blum RH, Brooks JS, Shiraki M, Frytak S, Parkinson DR. Randomized comparison of doxorubicin alone versus ifosfamide plus doxorubicin or mitomycin, doxorubicin, and cisplatin against advanced soft tissue sarcomas. J Clin Oncol 1993;11(7):1269-1275.

16. Spiro IJ, Rosenberg AE, Springfield D, Suit H. Combined surgery and radiation therapy for limb preservation in soft tissue sarcoma of the extremity: the Massachusetts General Hospital experience. Cancer Invest 1995;13(1):86-95.

17. Kaushal A, Citrin D. The role of radiation therapy in the management of sarcomas. Surg Clin North Am 2008;88(3):629-646.

18. O'Sullivan B, Davis AM, Turcotte R, Bell R, Catton C, Chabot P, Wunder J, Kandel R, Goddard K, Sadura A, Pater J, Zee B. Preoperative versus postoperative radiotherapy in soft-tissue sarcoma of the limbs: a randomised trial. Lancet 2002;359(9325):2235-2241.

19. Pisters PW. Treatment of localized soft-tissue sarcoma: lessons learned. Oncology (Williston Park) 2007;21(6):731-732, 735. 